\title{
Objawy choroby tkanki tącznej u chorej ze szpiczakiem plazmocytowym - opis przypadku
}

\section{Symptoms of connective tissue disease in a patient with multiple myeloma - a case report}

\author{
Małgorzata Rutecka ${ }^{凶}$, Marek Brzosko \\ Pomorski Uniwersytet Medyczny w Szczecinie, Klinika Reumatologii, Chorób Wewnętrznych i Geriatrii, ul. Unii Lubelskiej 1, 71-252 Szczecin \\ $\triangle$ malgorzata.rutecka@wp.pl
}

\begin{abstract}
Introduction: Multiple myeloma is a cancer of the lymphatic system characterized by the proliferation and accumulation of monoclonal plasma cells which in most cases produce monoclonal immunoglobulin. It occurs most often in the elderly. The first symptoms of myeloma are nonspecific. There are, among others, bone pain and weakness associated with anaemia. In advanced myeloma the symptoms mostly arise from the coexistence of osteolytic lesions and pathological fractures. The clinical presentation of multiple myeloma may resemble many other diseases, including rheumatic diseases.
\end{abstract}

Case report: In this publication, we present a case of a patient reporting symptoms of connective tissue disease in the course of multiple myeloma.

Conclusion: Symptoms of connective tissue disease may precede or mask the symptoms of cancer. In cases of uncharacteristic course diagnostics should always be expanded to consider proliferative diseases.

Keywords: monoclonal gammapathy; rheumatoid arthritis; Raynaud's phenomenon.

\begin{abstract}
ABSTRAKT
Wstęp: Szpiczak plazmocytowy jest chorobą nowotworową układu limfatycznego, która charakteryzuje się proliferacją i gromadzeniem monoklonalnych plazmocytów wytwarzających zwykle monoklonalną immunoglobulinę. Występuje najczęściej u ludzi starszych. Pierwsze objawy są nieswoiste, należą do nich m.in. bóle kostne oraz osłabienie związane z niedokrwistością. W zaawansowanym klinicznie szpiczaku objawy wynikają na ogół ze współwystępowania zmian osteolitycznych, a także złamań patologicznych. Szpiczak może przypominać obraz wielu innych chorób, w tym także chorób reumatycznych.
\end{abstract}

Opis przypadku: Przedstawiono przypadek chorej, która zgłaszała objawy choroby tkanki łącznej w przebiegu szpiczaka plazmocytowego.

Wnioski: Objawy układowej choroby tkanki łącznej mogą wyprzedzać lub maskować objawy choroby nowotworowej. W przypadkach niecharakterystycznego przebiegu zawsze należy poszerzyć diagnostykę w kierunku procesu rozrostowego. Słowa kluczowe: gammapatia monoklonalna; reumatoidalne zapalenie stawów; objaw Raynauda.

\section{WSTĘP}

Szpiczak plazmocytowy jest wieloetapowo przebiegającą chorobą, która charakteryzuje się proliferacją i gromadzeniem monoklonalnych plazmocytów wytwarzających najczęściej monoklonalną immunoglobulinę bądź jej fragmenty [1].

W 2010 r. szpiczak plazmocytowy był w Polsce trzecią pod względem liczby nowo zarejestrowanych przypadków chorobą nowotworową układu limfatycznego u dorosłych. Stanowi do 19\% nowotworów tego układu [2]. Występuje najczęściej u ludzi starszych, a szczyt zachorowalności przypada na 7. dekadę życia. Około 8\% chorych jest w wieku poniżej 60 r.ż., a $2 \%$ poniżej 40 r.ż. [1].

Pierwsze objawy szpiczaka są nieswoiste. Chorzy często zgłaszają ból w okolicy krzyżowej lub w innych częściach układu kostnego, osłabienie związane z niedokrwistością, pogorszenie stanu ogólnego. W zaawansowanym klinicznie szpiczaku objawy wynikają najczęściej ze współwystępowania zmian osteolitycznych, a także złamań patologicznych. Ponadto obserwuje się objawy zespołu nadlepkości, niewydolności nerek, hiperkalcemii oraz niedokrwistości [2].

Obraz kliniczny szpiczaka plazmocytowego nie zawsze jest jednoznaczny. Może przypominać wiele innych chorób, w tym także choroby reumatyczne. Aż u 80\% chorych z rozpoznanym szpiczakiem plazmocytowym można zaobserwować różnego typu patologie obejmujące układ kostny. Częstym objawem są bóle kostne, zwłaszcza kręgosłupa, zgłaszane nawet przez ponad połowę chorych [3, 4]. U 10-15\% chorych stwierdza się także osteopenię lub osteoporozę [3, 4, 5].W przebiegu szpiczaka mnogiego w wyniku odkładania się złogów amyloidu w strukturach stawowych może dojść do tzw. artropatii amyloidowej, która może występować nawet u $6 \%$ chorych ze szpiczakiem plazmocytowym [3]. Objawia się ona bólem i poszerzeniem obrysów zajętych stawów. Szczególnie w przypadkach z zajęciem 
wielu stawów należy różnicować występujące objawy z chorobami zapalnymi stawów. Obserwuje się również współwystępowanie dny moczanowej i szpiczaka plazmocytowego [6, 7]. Zwiększenie stężenia kwasu moczowego we krwi wynika m.in. ze wzrostu metabolizmu zasad purynowych oraz z redukcji wydalania kwasu moczowego w wyniku narastającej niewydolności nerek [7]. Rzadziej opisywane są przypadki septycznego zapalenia stawów w przebiegu szpiczaka plazmocytowego. Jednocześnie autorzy podkreślają, iż jego wystąpienie wiąże się raczej z terapią szpiczaka niż z samym przebiegiem choroby [3].

W niniejszym artykule przedstawiono przypadek chorej ze szpiczakiem plazmocytowym, w przebiegu którego występowały objawy choroby tkanki łącznej. Prezentacja miała na celu zwrócenie uwagi na konieczność zachowania czujności onkologicznej w trakcie diagnostyki reumatologicznej.

\section{OPIS PRZYPADKU}

Chora w wieku 75 lat z występującymi od kilku miesięcy dolegliwościami bólowymi drobnych stawów rąk i stóp została przyjęta do kliniki celem diagnostyki i ewentualnego leczenia. W wywiadzie podała jednorazowy epizod obrzęków tych stawów przed rokiem, sztywność poranną stawów trwającą ok. 15 min, suchość spojówek oraz błon śluzowych, ból mięśni, zlewne nocne poty oraz od kilku lat objaw Raynauda. W czasie 3 miesięcy schudła $3 \mathrm{~kg}$ bez stosowania diety. Od wielu lat była leczona z powodu niewydolności serca, w związku z czym na stałe przyjmowała bisoprolol i torasemid.

W badaniu przedmiotowym stwierdzono powiększony węzeł chłonny podżuchwowy po stronie prawej, palpacyjnie niebolesny, ruchomy, o średnicy ok. $2 \mathrm{~cm}$, zaniki mięśni obręczy barkowej i biodrowej bez ich tkliwości, obustronne zaniki mięśni glistowatych i międzykostnych rąk. W chwili badania stawy nie były obrzęknięte ani bolesne. $\mathrm{W}$ badaniu jamy brzusznej brzeg śledziony był wyraźnie wyczuwalny pod łukiem żebrowym.

W badaniach laboratoryjnych zaobserwowano umiarkowaną niedokrwistość normocytarną ( $\mathrm{Hb}$ 9,6 g/dL, MCV 94,2 fl), obniżenie stężenia składowej C3 dopełniacza - 79,0 mg/dL (90,0-180,0 mg/dl), nieznacznie podwyższone parametry stanu zapalnego (OB $40 \mathrm{~mm} / \mathrm{h}$, CRP 5,85 mg/L), bezpośredni odczyn Coombsa słabo dodatni. Stężenie kinazy fosfokreatynowej było w zakresie normy (CPK 56 U/L). W wykonanych badaniach serologicznych stwierdzono przeciwciała przeciwjądrowe (anti-nuclear antibodies - ANA) w mianie 1 : 80 o jąderkowym typie świecenia, przeciwciała anty PM/Scl dodatnie w klasie IgG. Nie stwierdzono obecności czynnika reumatoidalnego (rheumatoid factor - RF), przeciwciał przeciw cyklicznemu cytrulinowanemu peptydowi (anti-cyclic citrullinated peptide antibodies - aCCP) oraz przeciwciał przeciw cytoplazmie neutrofilów (anti-neutrophil cytoplasmic antibodies - ANCA). W badaniu ultrasonograficznym w stawach promienno-nadgarstkowych, międzynadgarstkowych, promienno-łokciowych oraz większości stawów śródręczno-paliczkowych obserwowano przerost błony maziowej z umiarkowanie wzmożonym unaczynieniem oraz niewielki wysięk w tych stawach. W obrębie stawów międzypaliczkowych bliższych i dalszych stwierdzono umiarkowaną, a miejscowo nasiloną proliferację kostną, wśród której w obrębie V stawu międzypaliczkowego bliższego po stronie lewej stwierdzono obecność drobnej zmiany nadżerkowej, a w pozostałych stawach międzypaliczkowych bliższych nie można ich wykluczyć. Uwidoczniono obustronny zespół kanału nadgarstka: nerwy pośrodkowe w obrębie kanału nadgarstka były obustronnie obrzęknięte i pogrubiałe; pole powierzchni przekroju nerwów pośrodkowych na wysokości kości grochowatych wynosiło $18 \mathrm{~mm}^{2}$ po stronie prawej; po stronie lewej był nerw pośrodkowy dwudzielny o przekrojach 7 i $7 \mathrm{~mm}^{2}$. W tomografii komputerowej klatki piersiowej wykonanej pół roku wcześniej stwierdzono śladową ilość płynu w jamach opłucnowych oraz kilka zmian drobnoguzkowych. W wykonanej w tym samym czasie scyntygrafii kośćca nie uwidoczniono ognisk mogących odpowiadać zmianom nowotworowym. W kolonoskopii, mammografii oraz badaniu ultrasonograficznym piersi odchyleń nie znaleziono. $Z$ powodu obrzęków podudzi wykonano badanie ultrasonograficzne naczyń żylnych kończyn dolnych, w którym nie stwierdzono zakrzepicy żył głębokich.

W proteinogramie białek surowicy występował pik białka monoklonalnego oraz zwiększony odsetek gammaglobulin do 30\% (norma: 11,1-18,8\%), stężenie albumin 3,61 g/dL (norma: 4,02-4,76 g/dL), natomiast białko całkowite oraz pozostałe frakcje proteinogramu były w zakresie normy. Podwyższone było stężenie IgG: 23,86 g/dL (norma: 7,0-16,0 g/d), stężenie wapnia całkowitego było prawidłowe: $2,40 \mathrm{mmol} / \mathrm{L}$ (norma: 2,20-2,55 mmol/L), a stężenie wapnia zjonizowanego nieznacznie podwyższone do 1,35 mmol/L (norma: 1,12-1,32 mmol/L). W badaniu immunoelektroforetycznym białek surowicy wykryto białko monoklonalne IgG typu lambda, a w moczu białko Bence-Jonesa, łańcuchy lekkie lambda. Wykonano biopsję aspiracyjną szpiku z mostka, w której uwidoczniono zwiększony odsetek plazmocytów atypowych $13,4 \%$ oraz obecność form dwujądrowych, co mogło odpowiadać naciekowi w przebiegu szpiczaka. W badaniu radiologicznym czaszki, kręgosłupa piersiowego, lędźwiowo-krzyżowego oraz miednicy nie uwidoczniono ognisk osteolitycznych.

Ze względu na wyczuwalny, powiększony węzeł chłonny podżuchwowy prawy wykonano badanie ultrasonograficzne węzłów chłonnych na szyi, uwidaczniając dość liczne węzły chłonne z zachowanymi wnękami, niezakwalifikowane do biopsji. Na podstawie całości obrazu klinicznego rozpoznano szpiczaka plazmocytowego. U chorej stwierdzono następujące kryteria szpiczaka: białko monoklonalne obecne w surowicy i moczu, obecne atypowe plazmocyty w szpiku, niedokrwistość $(\mathrm{Hgb}<10 \mathrm{~g} / \mathrm{dL})$. Chora została zakwalifikowana do leczenia w Klinice Hematologii.

\section{DYSKUSJA}

U chorych z procesem rozrostowym mogą występować objawy charakterystyczne dla chorób reumatycznych [8]. Objawy te mogą być wywołane bezpośrednio przez toksyny wydzielane 
przez komórki guza, mogą też powstawać w reakcji nadwrażliwości albo być skutkiem uwolnienia wewnątrzkomórkowych antygenów [6]. Zdarza się, że u części chorych chorobę nowotworową rozpoznaje się dopiero po ponad 2 latach od pojawienia się pierwszych objawów reumatycznych [8].

W omówionym przypadku pacjentka zgłosiła się do kliniki z powodu dolegliwości bólowych stawów, będących jednym z częstszych powodów zgłaszania się chorych do lekarza. U pacjentki dolegliwości bólowe występowały od kilku miesięcy i dotyczyły głównie drobnych stawów rąk oraz stawów nadgarstkowych. Sztywność poranna trwała $15 \mathrm{~min}$. W zapaleniu stawów w przebiegu choroby nowotworowej sztywność poranna stawów trwa na ogół krócej niż w przebiegu reumatoidalnego zapalenia stawów [9]. Zazwyczaj nie obserwuje się obecności RF jak w prezentowanym przypadku bądź występuje on w niskim stężeniu. W badaniach serologicznych mogą pojawić się przeciwciała przeciwjądrowe w małym mianie [9]. U chorej ANA występowały w prawidłowym mianie, jednakże stwierdzono nieznacznie podwyższone stężenie przeciwciał anty PM/Scl. W wykonanym badaniu ultrasonograficznym uwidoczniono zapalenie błony maziowej z obecnością pojedynczych nadżerek. W zapaleniu stawów w przebiegu choroby nowotworowej zazwyczaj nie stwierdza się cech destrukcji kostnej, jednakże opisywane są przypadki zapalenia stawów w przebiegu szpiczaka plazmocytowego z obecnością nadżerek $[3,10]$. Obraz kliniczny może do złudzenia przypominać m.in. reumatoidalne zapalenie stawów wieku starszego, dlatego w każdym przypadku zapalenia stawów w wieku starszym bądź też ze współistniejącymi objawami ogólnymi (m.in. wzrost temperatury ciała, nocne poty, utrata masy ciała) należy przeprowadzić diagnostykę w kierunku nowotworu. Zapalenie stawów w przebiegu nowotworu najczęściej obserwuje się w przebiegu nowotworów płuc, sutka, żołądka oraz nowotworów układu chłonnego [9].

Chora zgłaszała również występujący od kilku lat objaw Raynauda. Objaw ten, występujący u osób powyżej 50. r.ż., może pojawić się w przebiegu nowotworów płuc, jelita cienkiego, gruczołu sutkowego, trzustki, a także nowotworów układu krwiotwórczego. Podejrzenie choroby nowotworowej powinno nasuwać występujące asymetryczne zajęcie palców rąk, szybko postępująca martwica, a także brak poprawy po zastosowanych lekach rozszerzających naczynia [7, 9, 11].

Prezentacja przypadku ma na celu zwrócenie uwagi na konieczność wnikliwej oceny chorego. Przyjmuje się, iż zapalenie stawów w przebiegu chorób nowotworowych przebiega bez obecności nadżerek, jednakże dostępne są opisy przypadków zapalenia stawów w przebiegu szpiczaka plazmocytowego z obecnymi nadżerkami. Szczególną czujność onkologiczną zatem należy zachować w przypadkach o nietypowym przebiegu, z szybko narastającymi objawami lub złą reakcją na klasyczne leczenie $[6,9]$. Należy mieć jednak na uwadze, że w niektórych chorobach reumatycznych znacznie częściej dochodzi do rozwoju pewnych typów nowotworów. Niewłaściwie postawiona diagnoza wiąże się z rozpoczęciem nieodpowiedniej terapii, a to zmniejsza szanse na wyleczenie.

\section{WNIOSKI}

Objawy układowej choroby tkanki łącznej mogą wyprzedzać lub maskować objawy choroby nowotworowej. W przypadkach niecharakterystycznego przebiegu zawsze należy poszerzyć diagnostykę w kierunku procesu rozrostowego.

\section{PIŚMIENNICTWO}

1. Gajewski P, editor. Interna Szczeklika. Podręcznik chorób wewnętrznych 2014. Kraków: Medycyna Praktyczna; 2014. p. 1713-9.

2. Zalecenia Polskiej Grupy Szpiczakowej dotyczące rozpoznawania i leczenia szpiczaka plazmocytowego oraz innych dyskrazji plazmocytowych na rok 2013. Acta Haematol Pol 2015;44:159-211.

3. Morais S, du Preez H, Akhtar MR, Cross S, Isenberg DA. Musculoskeletal compilations of haematological disease. Rheumatology (Oxford) 2016;55(6):968-81. doi: 10.1093/rheumatology/kev360.

4. Eslick R, Talaulikar D. Multiple myeloma: from diagnosis to treatment. Aust Fam Physician 2013;42(10):648-8.

5. Zamagni E, Cavo M. The role of imaging techniques in the management of multiple myeloma. Br J Haematol 2012;159(5):499-513. doi: 10.1111/ bjh.12007.

6. Świerkot J, Lewandowicz-Uszyńska A, Bogunia-Kubik K. Zespoły paranowotworowe a choroby reumatyczne. Postępy Hig Med Dośw 2014;68: 944-54.

7. Olas J, Bucka J. Objawy stawowe u pacjentów ze szpiczakiem mnogim. Prz Reumatol 2011;38:1-2.

8. Kwiatkowska B, Przygodzka M, Filipowicz-Sosnowska A. Objawy reumatyczne w chorobach nowotworowych. J Oncol 2006;56:693-9.

9. Dąbrowska-Zimoń A, Brzosko M. Reumatologiczne zespoły paranowotworowe - przegląd literatury. Ann Acad Med Stetin 2006;52 Suppl. 2:17-22.

10. Molloy CB, Peck RA, Bonny SJ, Jowitt SN, Denton J, Freemont AJ, et al. An unusual presentation of multiple myeloma: a case report. J Med Case Rep 2007;1:84. doi: 10.1186/1752-1947-1-84.

11. DeCross AJ, Sahasrabudhe DM. Paraneoplastic Raynaud's phenomenon. Am J Med 1992;92(5):571-2. 